\title{
Trend of Defect Occurrence Between Painting Work And Finish Work In Apartment Building
}

\author{
Junmo Park, Deokseok Seo
}

\begin{abstract}
In Korea, defect disputes regarding apartment buildings are becoming social issues. In particular, the term of warranty liability, which is an important criterion for defect disputes, lacks sufficient groundings for its establishment, leading to increased number of conflicts about the timing of defect occurrence as well as responsibilities for the defects. In the present research, we compare the trend of defect occurrence between painting work and finish work in apartment buildings during the last ten years to determine the validity of the current term of warranty liability. As a result, defect occurrence in painting work occurs from the first year to the fifth year. This trend is different from the finish work as a whole and also from the work which has one or two years of the term of warranty liability. Therefore, we recommend establishing a separate criterion for the term of warranty liability of painting work, which is different from other types of finish work.
\end{abstract}

Keywords--- Apartment Building, Defect Dispute, Trend of Defect Occurrence, Painting Work, Finish Work.

\section{Introduction}

Detached houses accounted for $87.5 \%$ during the 1980s, which dropped down to $27.3 \%$ in the 2010 s. On the contrary, apartment buildings accounted for only $7 \%$ during the $1980 \mathrm{~s}$ and increased to $59 \%$ in the 2010 s [1].

Multi-unit dwellings including apartment buildings became popular due to higher land use efficiency and standardized space and equipment which provide convenience to the tenants. However, an increase in the number of apartment buildings and diversified methods for housing supply entailed an increase in related disputes between the tenants. Representative social disputes occurred in apartment buildings include issues regarding the operation of self-government councils, the conflict with management office and noise complaints.

Among these disputes, a number of disputes concerning defects occurred in apartment buildings are becoming lawsuits; however, it is difficult to mediate the disputes between the tenants and business entities. In lawsuits, the

Revised Manuscript Received on July 05, 2019.

Junmo Park Kyungsan Engineering, 266 Seochodaero, Seocho-gu, 06646, Seoul, Korea

Deokseok Seo, Halla University, 28 Halla university-gil,Wonju-si, 26404, Gangwon-do, Korea responsibility for defect repairs is determined by considering the timing of defect occurrence, timing of defect repair request, timing of defect repair, and so on.

As the legal standards regarding the responsibility of defect repairs, the term of warranty liability is regulated in the Condominium Act, Housing Act, and Framework Act on the Construction Industry. The term of warranty liability orders the business entities which are responsible for the construction of apartment buildings to repair the defects occurred during a certain period. During this period, the divided owners have the right to request for defect repairs. Also, to prepare for the business entity becoming insolvent, there is a mandatory deposit for defect repairs and surety insurance to protect the rights of divided owners. The term of warranty liability is the base for establishing this term of defect repair warranty.

However, there is no clear standard or foundation for the term of warranty liability regulated in related regulations. Besides, although recently enacted Multi-family Housing Management Act provides an institutional foundation for reasonably resolving diverse disputes in apartment buildings, there are still no criteria and grounds for the term of warranty liability. In particular, a significant discrepancy in terms between types of facility constructions is likely to aggravate the disputes by legal conflicts and legal interpretation.

\subsection{Purpose}

Painting work in apartment buildings is the finish work that is important for tenants' lives and also from the aesthetic aspects. Also, painting work accounts for a large portion in the defect repair costs and often becomes the center of disputes since diverse types of defects occur [2]. However, although there are different types of finish work including the painting work, the findings from the previous literature suggest that there is a significant discrepancy between the painting work and other types of finish work [3]. Still, these previous studies have not pointed out the detailed differences.

Therefore, in this paper, we compare the trend of defect occurrence between the painting work and overall finish work as well as other types of work which have one year or two years of the term of warranty liability. We intend to confirm that the defect occurrence in the painting work is different from that of other types of work.

1.3 Scope and Method

Multi-unit dwellings are applied with different regulations depending on the timing of business approval.

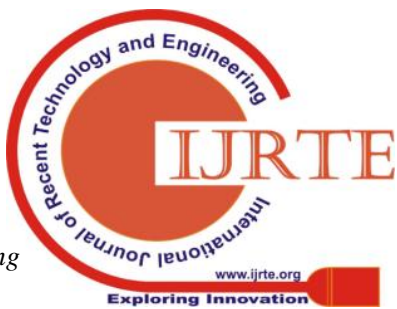


Also, not only there are diverse legislations about multi-unit dwellings including the Condominium Act, Housing Act, and Framework Act on the Construction Industry, but also the term of warranty liability differs by each regulation. We focus on the Housing Act enacted before the Multi-family Housing Management Act.

Besides, these regulations about housing do not necessarily define different terms of warranty liability for detached houses and multi-unit dwellings. However, since collective disputes are more prevalent in multi-unit dwellings than in detached houses, it is easier to acquire relevant data. Therefore, we analyze the data of multi-unit dwellings, by focusing on the apartment buildings.

The regulations in the Housing Act define the term of warranty liability differently for each type of work ranging from one to four years. In this paper, we focus on the painting work.

The research process is as follows. First, we examine the types of defect in painting work, the term of warranty liability in the regulations and the history of the regulations. Second, we investigate the status of defect occurrence in apartment buildings to analyze the number of defect occurrent by years and cumulative rate of occurred defects. Third, we analyze the difference in the trend of defect occurrence by classifying the work into overall finish work including painting work, overall finish work that has one year of the term of warranty liability and painting work.

Regarding the trend of defect occurrence, we calculate the timing when the cumulative rate of occurred defects exceeds $95 \%$ and $99 \%$. Also, we compare the timing when the cumulative rate of occurred defects exceeds $95 \%$ with the term of warranty liability.

\section{Literature Study}

\subsection{Definition of Painting Work Defect}

According to the term of warranty liability regulated in the Housing Act, the painting work is classified as one of the types of finish work. The painting work includes the painting of outer wall, inner wall and common areas such as the underground parking lot (e.g., the wall in overall, washboard painting, safety painting, finish painting of metallic materials). There is also painting work for the ceiling and wall in the balcony.

The types of defects occurred in painting work include "poor painting", "desquamation and exfoliation of painting" and "contamination of painting." [4]. These defects in painting work are rarely involved with safety or functional issues but there are issues from the aesthetic aspects.

\subsection{Term of Warranty Liability}

The term of warranty liability in the Housing Act is the exclusion period during which the divided owners have the right to request for defect repairs to the business entity [5]. Therefore, it is different from the defect repair period or mending and exchange period based on the long term repair plan.

The divided owners have the right to recognize the defects in their houses and request for their repair within the term of warranty liability [6]. This request for defect repair is an important foundation to estimate the time of defect occurrence. Therefore, in defect lawsuits regarding apartment buildings, the term of warranty liability is a standard of judgment that determines whether the defect lawsuit may make a case or not.

The regulations about the term of warranty liability of multi-unit dwellings are originated from the defect repair period included in the Rules on the Management of Apartment Houses in 1979. At this time, the term of warranty liability was not defined, but the defect repair period was included. In 1981, the Rules on the Management of Apartment Houses was eneacted and the term of warranty liability was defined for the first time.

\subsection{Revised History of Law}

The history of law revisions about the term of warranty liability is as follows. The Condominium Management Act was enacted in 1979, which defined five to ten years of the term of warranty liability for the form resistance structure. In 1982, the current form of defect repair period was established by construction types in the Rules on the Management of Apartment Houses. After that, matters regarding the term of warranty liability was transferred to the Condominium Management Act in 1998. In 2003, both the Condominium Management Act and Rules on the Management of Apartment Houses were abolished, transferring related regulations to the enforcement ordinance and enforcement regulation of the Housing Act. In 2007, the enforcement ordinance of the Housing Act was revised by adding a new type of facility construction and being changed to the term of warranty liability [7].

\subsection{Limitation of Housing Law}

Regarding the history of the term of warranty liability for painting work, the Rules on the Management of Apartment Houses (1981) classified painting work into the painting of internal and external metal base and painting of concrete and mortar base. It defines the term of defect repair as one year. However, there is no history of enactment or revision which explains the grounds for this one-year term.

In 1982, the name was changed to painting work, and it was classified as one of the types of finish work. There have been several revisions on the regulation, but only the term of defect repair became the term of warranty liability. Regulations regarding the

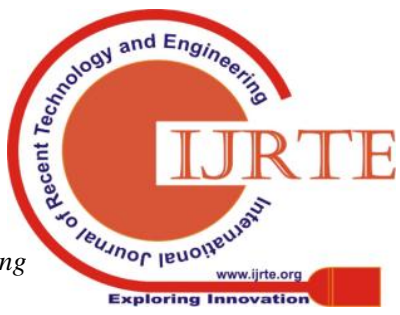


painting work have remained the same.

Besides, in the Multi-family Housing Management Act recently enacted in 2016, the term of warranty for overall finish work, including the painting work, became two years. However, despite the enactment of the Multi-family Housing Management Act, there are no grounds for the term of warranty liability of the paintaing work.

\section{Case Study}

\subsection{Outline}

In the present research, we examine the defects occurred in the painting work of apartment buildings to identify the trend and tendency of defect occurrence. Based on this analysis, we compare the trend with the current term of warranty liability. We investigated 125,816 units in 177 apartment complexes that were constructed from 2002 to 2011.

Regarding the distribution of defect occurrence in overall finish work, the painting accounts for approximately $9.4 \%$. Other types of finish work with an one-year term of warranty liability such as wallpaper work, interior finishing work and plastering work account for $35.5 \%$. The types of finish work with a two-year term of warranty liability such as tile work, indoor furniture work and insulation work account for $55.1 \%$ (Figure 1).

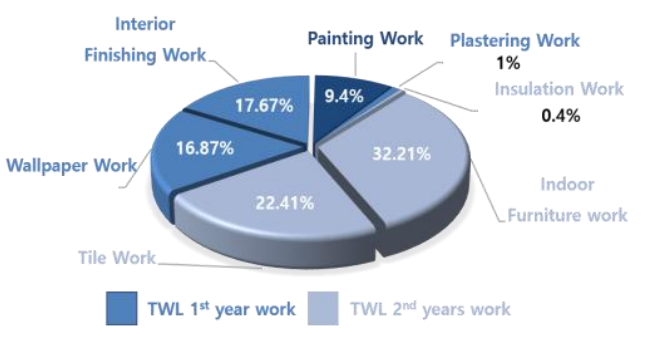

\subsection{Trend of Occurred Defect in Finish Work}

Figure 2 demonstrates the trend of defects occurred in finish work by years. The number of defects occurred during the $1^{\text {st }}$ year accounts for $71.6 \%$ and $19.4 \%$ in the $2^{\text {nd }}$ year. The cumulative rate of occurred defects exceeds $95 \%$ from the $3^{\text {rd }}$ year. The defects after the $5^{\text {th }}$ year are very rare.

The term of warranty liability for finish work varies by the types of work and ranges from one to two years. Even for the term of warranty liability of two-years, there is an one-year discrepancy with the timing when the cumulative rate of occurred defects exceeds $95 \%$.

Figure 1: Distribution of Occurred Defect in Finish Work
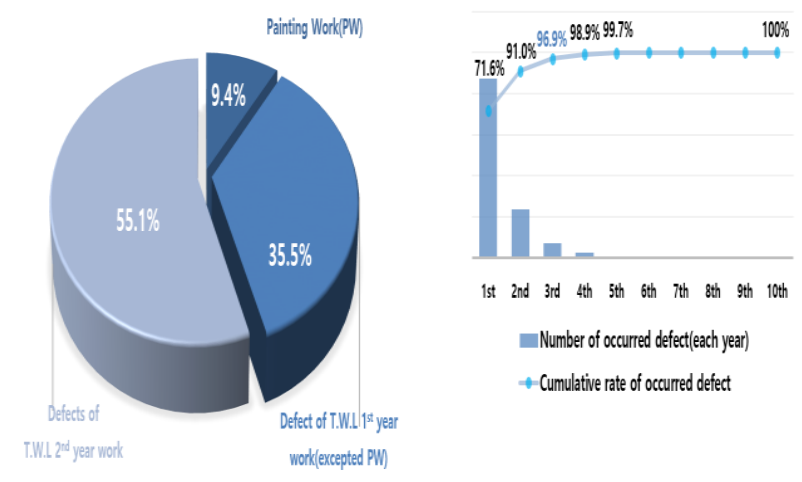

\subsection{Trend of Occurred Defect in Finish Work as T.W.L $1^{\text {st }}$ year}

Figure 3 demonstrates the trend of defects occurred in finish work by years, of which the term of warranty liability is one year. The number of defects occurred during the 1st year accounts for $75.4 \%$ and $16.8 \%$ in the 2 nd year. The cumulative rate of occurred defects exceeds $95 \%$ from the $3 \mathrm{rd}$ year. The defects after the $4^{\text {th }}$ year are below $1 \%$.

The term of warranty liability is one year, and there is a two-year discrepancy with the timing when the cumulative rate of occurred defects exceeds $95 \%$.
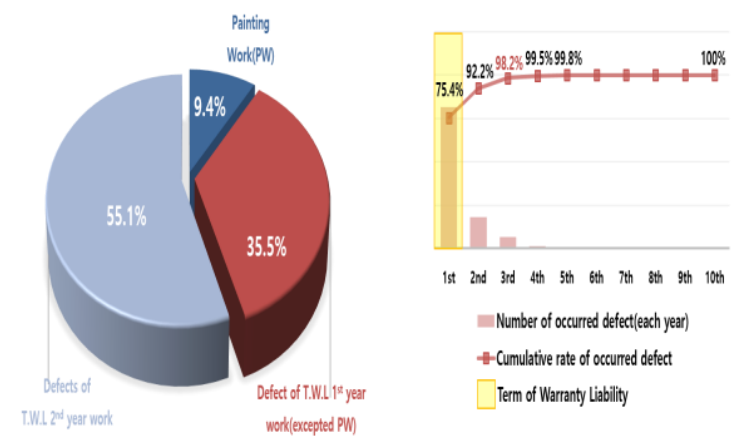

\subsection{Trend of Occurred Defect in Finish Work as T.W.L $2^{\text {nd }}$ year}

Figure 4 demonstrates the trend of defects occurred in finish work by years, of which the term of warranty liability is two years. The number of defects occurred during the 1st year accounts for $71.5 \%$ and $21.0 \%$ in the 2 nd year. The cumulative rate of occurred defects exceeds $95 \%$ from the $3 \mathrm{rd}$ year. The defects after the $4^{\text {th }}$ year are below $1 \%$.

The term of warranty liability is two years, and there is an one-year discrepancy with the timing when the cumulative rate of occurred defects exceeds $95 \%$.

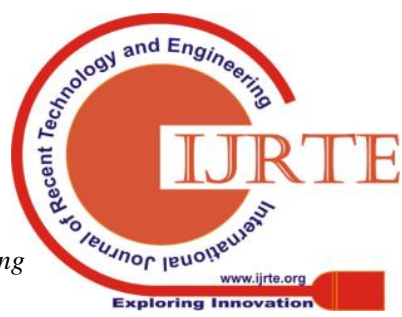



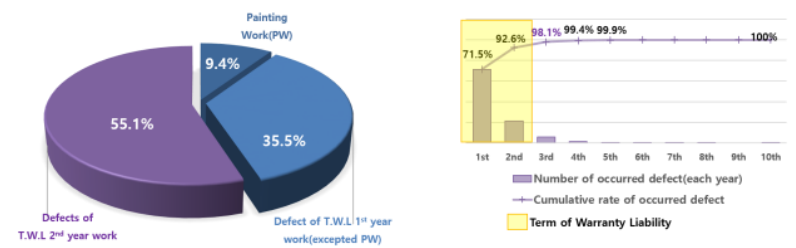

Figure 4: Trend on Occurred Defect in Finish Work as T.W.L $2^{\text {nd }}$ year

\subsection{Trend of Occurred Defect in Painting Work}

Figure 5 demonstrates the trend of defects occurred in painting work by years. The number of defects occurred during the 1 st year accounts for $57.6 \%$ and $20.1 \%$ in the 2 nd year. The cumulative rate of occurred defects exceeds $95 \%$ from the $5^{\text {th }}$ year. The defects after the $6^{\text {th }}$ year are very rare.

The term of warranty liability for painting work is one year, and there is a four-year discrepancy with the timing when the cumulative rate of occurred defects exceeds 95\%. The discrepancy is significantly larger than the overall finish work and other types of finish work with one-year term of warranty liability.
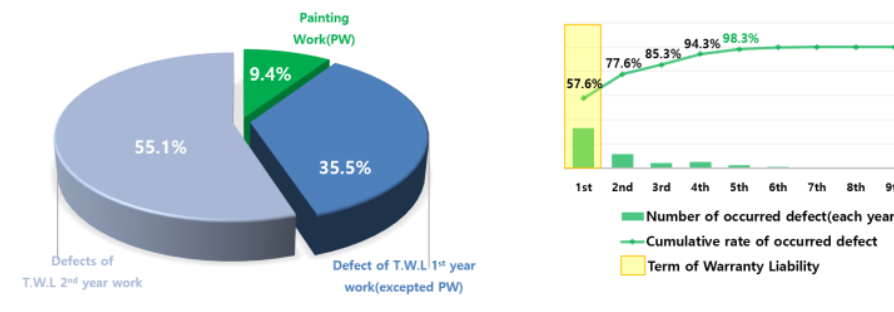

Figure 5: Trend on Occurred Defect in Painting Work

\subsection{Result}

The results of the analysis are as follows. First, the portion of defect occurrence of the painting work during the $1^{\text {st }}$ year is $57.6 \%$ which is lower than other types of work. Second, in other types of finish work except for the painting work, the number of defects within the $3^{\text {rd }}$ year accounts for more than 95\% whereas in the painting work, the cumulative rate of occurred defects exceeds $95 \%$ from the $5^{\text {th }}$ year. Third, as a result of comparing the timing when the cumulative rate of occurred defects exceeds $95 \%$ and the current term of warranty liability, the painting work demonstrates a four-year discrepancy, which is greater than other types of work (Table $1)$.

\begin{tabular}{|c|c|c|c|}
\hline Defect & $\begin{array}{l}\text { Term of } \\
\text { Warranty } \\
\text { Liability } \\
\text { (A) }\end{array}$ & $\begin{array}{l}\text { Term of over } \\
\text { 95\% } \\
\text { Cumulative } \\
\text { Occurrence } \\
\text { (B) }\end{array}$ & $\begin{array}{l}\text { Difference } \\
\text { (A-B) }\end{array}$ \\
\hline Total Finish Work & $1^{\text {st }} \sim 2^{\text {nd }}$ year & $3^{\text {rd }}$ year & 1 year \\
\hline $\begin{array}{lll}\text { T.W.L } & 1^{\text {st }} \quad \text { year } \\
\text { Work } & & \end{array}$ & $1^{\text {st }}$ year & $3^{\text {rd }}$ year & 1 year \\
\hline $\begin{array}{l}\text { T.W.L } 2^{\text {nd }} \text { year } \\
\text { Work }\end{array}$ & 2 years & $3^{\text {rd }}$ year & 1 year \\
\hline Painting Work & $1^{\text {st }}$ year & $5^{\text {th }}$ year & 4 years \\
\hline
\end{tabular}

\section{III.Implication and Limitation}

\subsection{Implication}

The implications as a result of the above analysis are as follows. The trend of defect occurrence of the painting work is sigionificantly different from other types of finish work. In particular, it is notable that the trend is largely different between the painting work and other types of work with an one-year term of warranty liability.

Similarly, one of the previous studies found that disaster prevention work demonstrates a significantly different trend of defect occurrence when compared to other types of communication work [7].

As such, even when it is classified as the same type of work with the same term of warranty liability according to the Housing Act, the actual trend of defect occurrence can be different from one another. Therefore, the actual trend should be taken into consideration when revising the term of warranty liability in the future.

\subsection{Limitation}

However, the present research does not include the analysis of the factors affecting the defects of the painting work and how the trend varies depending on those factors. Future research should focus on verifying the factors to establish objective grounds and standards for the term of warranty liability.

Published By:

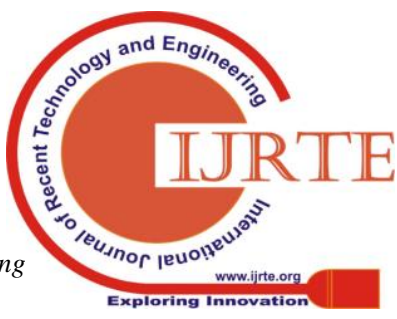




\section{Conclusion}

The term of warranty liability, which is an important criterion for defect disputes, lacks the concrete foundation for its establishment, leading to aggravated disputes followed by ambiguous legal interpretation of responsibilities.

Therefore, in the present research, we compare the trend of defect occurrence between the painting work and finish work to examine the validity of the current term of warranty liability. The results are as follows.

First, the defects of painting work occur from the $1^{\text {st }}$ year to the $5^{\text {th }}$ year, of which the trend of defect occurrence is significantly different from other types of finish work. Second even when compared with other types of work with an one-year term of warranty liability, the trend of defect occurrence of the painting work is peculiar. Third, the trend of defect occurrence of the painting work is significantly different from other types of finish work.

In this sense, when revising the term of warranty liability in the future, the actual trend of defect occurrence should be considered and a separate standard should be applied even when the types of work fall under the same category or have the identical term of warranty liability according to the current legislation.

\section{ACKNOWLEDGMENT}

This work was supported by the National Research Foundation of Korea (NRF) grant funded by the Korea government (2016R1A2B4012485).

\section{REFERENCES}

[1]Junmo Park and Deoseok Seo. Basic Study on Standard Process Model for Defect Consulting in Korea. Proceeding of International Workshops Material, Architecture and Civil Engineering, 2014.

[2]Beopsu Kim, Junmo Park, Jeonghyun Choi, Deokseok Seo, and Okkyue Kim. Comparative Analysis on Repairing Cost of Lawsuit on Concrete Crack Defect in Apartment Building. Korean Journal of Construction Engineering and Management, 12 (2011) 142-150.

[3]Junmo Park and Deoseok Seo. Basic Study on Term of Warranty Liability for Finish Work Defect in Apartment Building. International Journal of Research in Chemical, metallurgical and Civil Engineering, 4 (2017) 7-12.

[4]Korean Institute of Construction Engineering and Management. A Research for Judged Standard, Investigated Method and estimated Costing of Defect in Apartment Building. Korean Institute of Work Engineering and Management, Seoul, Korea, 2012.

[5]Junmo Park and Deoseok Seo. Analytical Study on Term of Warranty Liability in Window and Door Work Defect in Apartment Building of Korea Based on Defect Performance Data, Journal of Advanced Research in Dynamical and Control Systems, 10 (2018) 234-239.

[6]Junmo Park and Deoseok Seo. Basic Study on Term of Warranty Liability for Window and Door Work Defect in Apartment Building, Proceeding of International Conference on Research \& Innovation in Environment, Civil and Architecture Engineering, (2017) 127-135.

[7] Junmo Park and Deoseok Seo. Comparative Review on Term of Warranty Liability and Trend of Occurred Defect to Telecommunication Equipment Work in Apartment Buildings, International Journal of Research in Chemical, metallurgical and Civil Engineering, 15 (2018) 1781-1793.

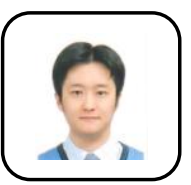

Junmo Park was born in 1980 in Seoul, South Korea. He currently lives in Seoul and works for Kyungsan Engineering. He majored in Architectural Engineering at the Chungbuk National University in Korea, graduated in 2006 with a master's degree in 2008, and received his Ph.D in 2012. Since 2005, he has been involved in various research and development projects commissioned by the Korean government and corporations and has lectured at many universities since 2010. Research on the defects of apartment buildings has been carried out with Professor Deokseok Seo, with support from Korean government over 5 projects since 2008. Currently, he is working with Professor Deokseok Seo on the term of warranty liability for apartment housing.

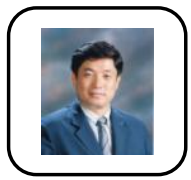

Deokseok Seo was born in Gongju, Korea in 1964. He currently lives in Wonju, Korea and is a professor of the College of Architecture at Halla University. He received bachelor's, master's, and doctoral degrees from Korea University in Korea. He also worked as a researcher at Korea Land \& Housing Corporation, the only professional public company in Korea's apartment houses. He is the first researcher who received a doctorate in research on defects in apartment housing in Korea. Until now, he has been conducting various researches with government support on defects in apartment houses. In 2016, he was also listed in the World Dictionary of Marquis Who's Who in the World. In addition, he received a commendation from the Minister of Education as an excellent researcher. He has done various researches with Dr. Junmo Park, and has written academic papers and thesis. Recently, with the support of the Korea Research Foundation, a specialized research institute under the Ministry of Education, Korea, he is conducting a study on the term of warranty liability in apartment buildings.
Published By:

Blue Eyes Intelligence Engineering \& Sciences Publication

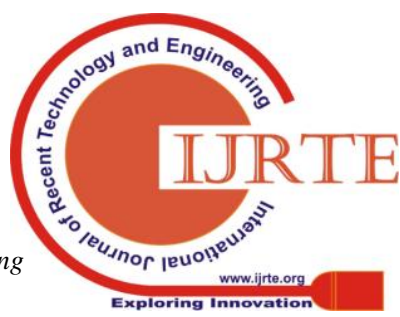

